\title{
Domestic experience of application of crossing in herds of Ukrainian cows of red-spotted and black-spotted dairy breeds
}

\author{
Bashchenko M. ${ }^{1}$, Boiko O. ${ }^{2}$, Sotnichenko Yu. ${ }^{3}$, Tkach Ye. ${ }^{4}$ \\ Cherkasy Experimental Station of Bioresources of NAAS \\ 76, Pasterivska Str., Cherkasy, 18036, Ukraine \\ e-mail: ${ }^{1}$ bioresurs.ck@ukr.net, ${ }^{2} a l e k s b o y 18 @ m e t a . u a,{ }^{3}$ sotnichenko.yulya@gmail.com, ${ }^{4}$ eftkach@i.ua \\ ORCID: ${ }^{1}$ 0000-0002-2872-7055, ${ }^{2} 0000-0002-3917-5583,{ }^{3} 0000-0003-2520-298 X,{ }^{4} 0000-0002-7736-9696$
}

Goal. To study the influence of selection of breeders of Montbeliard, Holstein, and Norwegian red breeds in herds of cows of Ukrainian red-spotted and black-spotted dairy breeds on the productivity of dairy cattle. Methods. Analysis of experimental research in the application of efficient breeding methods, theoretical analysis, formulation of hypotheses, genealogical, biometric and statistical methods, assessment of productive qualities of animals. Results. Higher milk yields were obtained from local first-born cows for the first 100 and 200 days of lactation: by $240 \mathrm{~kg}$ and $517 \mathrm{~kg}(\mathrm{P}>0.999)$ from crossbreeds of Ukrainian red-spotted dairy and Montbeliard breeds; by $338 \mathrm{~kg}(P>0.99)$ and $883 \mathrm{~kg}(P>0.999)$ from crossbreeds of Ukrainian black-spotted dairy breed and Norwegian. Similarly, the predominance of mixtures as to the fat and protein content in milk was observed. Crossed first-born cows outnumbered purebred peers in terms of smaller service period - for 24 days $(P>0.99)$ among crossbreeds of Ukrainian red-spotted dairy and Montbeliard breed; for 32 days $(P>0.999)$ among crossbreeds of Ukrainian black-spotted dairy breed and Norwegian, the number of inseminations per 1 fertile (less than 1.4 times among crossbreeds of Ukrainian red-spotted dairy breed and Montbeliard breed; and 1.69 times among crossbreeds of Ukrainian black-spotted dairy breed and Norwegian), the safety of the number of first-born cows in the herd increased by 94.4 and $96.7 \%$. Conclusions. Crossed first-borns obtained from the selection of breeders of Montbeliard and Norwegian red breeds outnumbered their peers obtained from Holstein bulls: by milk yield - on $324-425 \mathrm{~kg}(P>0.999)$, by fat content in milk - on $0.14-0.61 \%(P>0.95)$, and by protein - on $0.09-0.13 \%$, by the coefficients of milk yield, constancy of lactation, reproductive capacity and safety of first-borns for the 1 -st lactation.

Key words: Montbeliard, Norwegian red, lightness of calves, crossbreed.

DOI: https://doi.org/10.31073/agrovisnyk202105-06

Recently, the world has successfully implemented programs to cross the Holstein breed with animals of Ayrshire, Swedish red, Danish red, Jersey and Swiss breeds, which demonstrate a high level of productivity and quality of milk, productive longevity and reproduction [1].

In the United States, interbreeding programs have also developed and become popular. In California at the beginning of the XXI century. Montbeliards from France were intensively used for crossing with Holstein animals [2]. According to the productive characteristics of the obtained mixtures, there was an increase in profit, compared to Holsteins, in the range of $30-36 \%$, a decrease in the cost of veterinary drugs by $9.4 \%$, an increase in productive longevity - by $26 \%$, - 3rd lactations [3].

According to foreign researchers, a slight loss of milk yield of hybrid animals compared to purebred Holsteins is compensated by a decrease in the proportion of problem calves, the number of stillborn calves, shortening the service period, increasing the safety of calves and cows during the first lactation. milk quality, protein and fat content $[3,4]$.

The choice of breeds is individual in each case depending on the purpose of dairy production and further processing of the obtained products, and should be based on optimal levels of management, feeding regime, feed composition and other criteria [5].

Ukrainian red and black-spotted dairy breeds, like any biological system, are in constant variability and need constant control and improvement on such specific features as reproductive capacity, quality composition of milk, preservation of cows [6].

The purpose of research - to study the influence of selection of breeders of Montbeliard, Holstein and Norwegian red breeds in herds of cows of Ukrainian black and white and red and white dairy breeds on the productivity of dairy cattle.

Materials and methods of research. The research were conducted during 2019-2020 in the conditions of PJSC RPA "Progress" (15 heads of Ukrainian black and white dairy, 15 heads of Ukrainian red and white dairy breeds, 30 heads of crossbreeds 1/2URW1/2M) and breeding plant PJSC DG "Zolotonosha" (20 goals of Ukrainian red and white dairy breeds and 20 heads of crossbreeds 1/2URW1/2M) of Zolotonosha district, AS "Lan" (35 heads of Ukrainian black and white dairy breed, 96 heads of crossbreeds 1/2URW1/2NR) of Chornobayiv district., Subsidiary APRC "Vidrodgennya" (45 heads of Ukrainian red and white dairy breed and 45 heads of crossbreeds 1/2URW1/2M) Shpola district. 
Comparative evaluation of animals on productive traits was carried out within breeding herds, taking into account the structure of the genotype of animals. The quality of milk was assessed by fat content, protein and sanitary and hygienic indicators in accordance with DSTU ISO 1211: 2002.

To assess the nature of lactation of cows were determined: the coefficient of constancy of lactation - by I. Johansson and A. Hanson [7] through the ratio of milk yield for the second 100 days of lactation to the first 100, multiplied by 100; indicator of completeness of lactation according - by V.B. Veselovsky [8] - due to the ratio of actual milk yield to the maximum possible (product of higher daily milk yield and the number of milking days).

The reproductive capacity of cows was assessed by the age of the first insemination, the duration of service, dry and intercorporeal periods, the coefficient of reproducibility (KRA), which was determined by the formula of I. Doha, the ease of passage (points) [9]. The paper uses theoretical analysis, formulation of hypotheses, genealogical, biometric and statistical methods [10], assessment of the genotype of animals using computer programs "Orsek" and "Statistica".

Research results. Among the surveyed cows, the maximum average daily milk yield was obtained in the first 100 days of lactation: among the first-born Ukrainian red and white dairy $-23.3 \pm 2.71 \mathrm{~kg}$, Ukrainian black and white dairy breed $-23.8 \pm 2.41 \mathrm{~kg}$, local first-born genotype $1 / 2 \mathrm{URW} 1 / 2 \mathrm{M}-25.7 \pm 3.01 \mathrm{~kg}$, genotype $1 / 2$ URW1/2NR - $23.8 \pm 2.72 \mathrm{~kg}$ (Table 1).

Higher milk yields were obtained from local first-borns during the first 100-200 days of lactation (1/2URW1/2M $-2572 \pm 36.9 \mathrm{~kg}$ and $4914 \pm 56.9 \mathrm{~kg} ; 1 / 2 \mathrm{URW} 1 / 2 \mathrm{NR}-2720 \pm 62.5$ and $5073 \pm 56.5 \mathrm{~kg}$ ) compared with the primates obtained by purebred breeding (URW $-2332 \pm 48.6$ and $4397 \pm 52.2 \mathrm{~kg}$; URW $-2382 \pm 56.8$ and 4190 $\pm 56.4 \mathrm{~kg})$.

\section{Milk productivity of first-born cows}

\begin{tabular}{|c|c|c|c|c|}
\hline \multirow{2}{*}{ Indicator } & \multicolumn{4}{|c|}{ Breed/genotype } \\
\hline & URW & 1/2URW1/2M & UBW & 1/2UBW1/2NR \\
\hline Livestock, heads & 90 & 95 & 50 & 96 \\
\hline Yeld for 100 days of lactation, $\mathrm{kg}$ & $2332 \pm 48,6$ & $2572^{* * *} \pm 36,9$ & $2382 \pm 86,3$ & $2720^{* * *} \pm 62,5$ \\
\hline Fat content, \% & $3,34 \pm 0,023$ & $4,12^{* * *} \pm 0,052$ & $3,29 \pm 0,065$ & $3,56^{*} \pm 0,086$ \\
\hline Protein content, $\%$ & $3,14 \pm 0,011$ & $3,31^{* * *} \pm 0,042$ & $3,11 \pm 0,035$ & $3,19 \pm 0,021$ \\
\hline Yeld for 200days of lactation, $\mathrm{kg}$ & $4397 \pm 52,2$ & $4914^{* * *} \pm 56,9$ & $4190 \pm 56,4$ & $5073^{* * *} \pm 56,5$ \\
\hline Fat content, $\%$ & $3,51 \pm 0,018$ & $4,21^{* * *} \pm 0,058$ & $3,37 \pm 0,041$ & $3,71^{\text {*t }} \pm 0,056$ \\
\hline Protein content, $\%$ & $3,17 \pm 0,024$ & $3,36^{*} \pm 0,075$ & $3,18 \pm 0,056$ & $3,26 \pm 0,035$ \\
\hline Yeld for 305 days of lactation, $\mathrm{kg}$ & $5852 \pm 43,2$ & $6277^{* * *+} \pm 62,4$ & $6017 \pm 56,4$ & $6341^{* * *} \pm 74,8$ \\
\hline Fat content, \% & $3,54 \pm 0,22$ & $4,15^{* *} \pm 0,041$ & $3,48 \pm 0,031$ & $3,62^{*} \pm 0,055$ \\
\hline Protein content, \% & $3,21 \pm 0,074$ & $3,30 \pm 0,035$ & $3,10 \pm 0,034$ & $3,23 \pm 0,069$ \\
\hline Live weight, kg & $564 \pm 9,5$ & $622 \pm 59,8$ & $558 \pm 52,6$ & $556 \pm 9,8$ \\
\hline Coefficient of milk yield, $\mathrm{kg}$ & $9,18 \pm 0,012$ & $10,47^{* * *} \pm 0,012$ & $9,38 \pm 0,021$ & $10,32^{* * *} \pm 0,025$ \\
\hline $\mathrm{ICL}, \%$ & $82,4 \pm 0,71$ & $73,2^{* * *} \pm 0,39$ & $82,8 \pm 0,20$ & $76,4 \pm 0,44$ \\
\hline $\mathrm{CCL}, \%$ & $88,5 \pm 0,38$ & $88,1 \pm 0,84$ & $75,9 \pm 0,26$ & $86,5^{* * *} \pm 0,47$ \\
\hline
\end{tabular}

The qualitative composition of milk (fat and protein content) changed during different periods of lactation. The fat content in milk was higher among the group of local first-borns: among daughters, obtained from bulls of the Montbeliard breed - from $4.12 \pm 0.052 \%$ to $4.21 \pm 0.058 \%$; from breeding bulls of the Norwegian red breed - from $3.56 \pm 0.086 \%$ to $3.71 \pm 0.056 \%$. In terms of protein content in milk, local first-borns outnumbered those obtained from Holstein breeders: crossbreeds of genotype 1/2URW1/2M cows of first-born Ukrainian red and white dairy breed by $0.09-0.19 \%$, crossbreeds of genotype 1/2URW1/2NR Ukrainian first-born cows black and white dairy breed - by $0.08-0.13 \%$.

The milk yield coefficient, which reflects the efficiency of the animal's body, among the first-born Ukrainian red and white and black and white dairy breeds was $9.18 \pm 0.012-9.38 \pm 0.021$; mixtures of genotype $1 / 2 \mathrm{RW} 1 / 2 \mathrm{M} 10,47 \pm 0,012$, genotype 1/2BW1/2NR 10,32 $\pm 0,025$.

The index of completeness of lactation, which indicates the degree of realization of the potential of animals for milking was higher in the first-born Ukrainian black and white and red and white dairy breeds: $82.8 \pm 0.20 \%$ and $82.4 \pm 0.71 \%$. This gives grounds to claim that the potential of the first-born genotypes $1 / 2 \mathrm{URW} 1 / 2 \mathrm{M}$ and $1 / 2$ UBW1/2NR was not fully realized.

The coefficients of constancy of lactation among primiparous women are high (from $75.9 \pm 0.26$ to $86.5 \pm$ $0.47 \%$ ) and indicate a stable lactation curve during the first 200 days of lactation. The use of Montbeliard and Norwegian red bulls for reproduction of the uterine population did not reduce the milk yield and the quality of the milk in the conditions of intensive operation.

Independently and with the help of $1-2$ people (Table 2) calved $71.6 \%$ of first-born cows of genotype 1/2URW1/2M, 78.1\% - genotype 1/2UBW1/2NR. When inseminating cows of Ukrainian red and white and Ukrainian black and white dairy breeds with bulls of Holstein breed, the share of heavy calves increased from 
$23.3 \%$ (URW) to $28.0 \%$ (UBW), and the number of stillborn off spring - from 7.8-8.0\%. When using Norwegian red bulls, the lowest percentage of offspring stillbirth was obtained $-0.9 \%$.

\section{Reproductive capacity of first-born cows}

\begin{tabular}{|c|c|c|c|c|c|c|}
\hline \multirow{2}{*}{\multicolumn{3}{|c|}{ Indicator }} & \multicolumn{4}{|c|}{ Breed/genotype } \\
\hline & & & URW & 1/2URW1/2M & UBW & 1/2UBW1/2NR \\
\hline \multicolumn{3}{|c|}{ Livestock, heads } & 90 & 95 & 50 & 96 \\
\hline \multirow{6}{*}{ 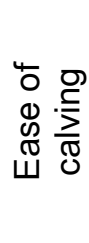 } & \multirow{2}{*}{$\begin{array}{l}\text { easy } \\
\text { (1-2 points) }\end{array}$} & $\%$ & 56,7 & 71,6 & 54,0 & 78,1 \\
\hline & & heads & 51 & 68 & 27 & 75 \\
\hline & \multirow{2}{*}{$\begin{array}{l}\text { medium } \\
(3 \text { points })\end{array}$} & $\%$ & 20,0 & 24,2 & 18,0 & 15,6 \\
\hline & & heads & 18 & 23 & 9 & 15 \\
\hline & \multirow{2}{*}{$\begin{array}{l}\text { heavy } \\
\text { (4-5 points) }\end{array}$} & $\%$ & 23,3 & 4,2 & 28,0 & 6,2 \\
\hline & & heads & 21 & 4 & 14 & 6 \\
\hline \multirow{2}{*}{\multicolumn{2}{|c|}{ Stillborn calves }} & $\%$ & 7,8 & 3,2 & 8,0 & 0,9 \\
\hline & & heads & 7 & 3 & 4 & 1 \\
\hline \multicolumn{3}{|c|}{ Duration of the service period, days } & $118 \pm 6,1$ & $94^{\star *} \pm 4,8$ & $119 \pm 6,6$ & $87^{* * *} \pm 6,3$ \\
\hline \multicolumn{3}{|c|}{$\begin{array}{l}\text { Number of inseminations per } 1 \text { fertile, } \\
\text { times }\end{array}$} & $3,48 \pm 0,571$ & $2,08 \pm 0,655$ & $3,55 \pm 0,864$ & $1,86 \pm 0,468$ \\
\hline \multicolumn{3}{|c|}{ Preservation of firstborns, $\%$} & 68,7 & 96,7 & 72,9 & 94,4 \\
\hline
\end{tabular}

Among the first-born cows of the Ukrainian red-spotted dairy breed, the average age of the first calving was $30.1 \pm 0.97$ months, the duration of the service period was $118 \pm 6.1$ days, fertilized after the first insemination - $32.1 \%$, the number of inseminations per fertile $-3.48 \pm 0.571$ times, the survival of first-borns after the first calving - 68.7\%; first-born cows of the Ukrainian black-spotted dairy breed - average age of the first calving 29.8 \pm 0.76 months, duration of the service period $-119 \pm 6.6$ days, fertilized after the first insemination $-32.0 \%$, number of inseminations per fertile $-3.55 \pm 0.864$ times, the survival of first-borns after calving $-72.9 \%$.

First-born hybrid cows outnumbered purebred peers in terms of: among cows of genotype 1/2URW1/2M received a shorter service period - by 24 days $(P>0.99)$, decreased the number of inseminations per 1 fertile (1.4 times), increased safety livestock of first-born cows in the herd; among cows of genotype 1/2URW1/2NR the period before the 1st insemination after calving was less by 32 days $(P>0.999)$, decreased the number of inseminations per 1 fertile (1.69 times), the safety of the number of first-born cows in the herd was $94,4 \%$.

\section{Conclusions}

Crossed first-borns obtained from the selection of breeders of Montbeliard and Norwegian red breeds outnumbered their peers obtained from Holstein bulls: by milk yield - on 324-425 kg ( $P>0.999)$, by fat content in milk - on $0.14-0.61 \%$ ( $P>0.95)$, and by protein - on 0.09-0.13\%, by the coefficients of milk yield, constancy of lactation, reproductive capacity and safety of first-borns for the 1-st lactation.

\section{References}

1. Matthews, D., Kearney, J.F., Cromie, A.R., et. al. (2019). Genetic benefits of genomic selection breeding programmes considering foreign sire contributions. Genet Sel Evol., 51(1), 40 doi: 10.1186/s12711-0190483-5.

2. Shonka-Martin, B., Heins, B., Hansen, L. (2019). Threebreed rotational crossbreds of Montbéliarde, Viking Red, and Holstein compared with Holstein cows for feed efficiency, income over feed cost, and residual feed intake. J. Dairy Sci., 102(4), 3661-3673. doi: 10.3168/jds.2018-15682.

3. Khayatzadeh, N., Mészáros, G., Utsunomiya, Y. et al. (2018). Effects of breed proportion and components of heterosis for semen traits in a composite cattle breed. J. Anim Breed Genet., 135(1), 45-53. doi: 10.1111/jbg.12304.

4. Rodríguez-Bermúdez, R., Miranda, M., Baudracco, J., et al. (2019). Breeding for organic dairy farming: what types of cows are needed? J. Dairy Res., 86(1), 3-12. doi: 10.1017/S0022029919000141.

5. Kramarenko, S.S., Kuzmichova, N. I., Kramarenko, O. S. (2018). Analiz vzaiemodii «henotyp $\times$ seredovyshche» na molochnu produktyvnist koriv [Analysis of the interaction "genotype $\times$ environment" on milk productivity of cows]. Scientific herald of LNUVMB named after S.Z, Gzycki, 20 (89). doi: 2734;10.32718/nvlvet8905. [in Ukrainian].

6. Bashchenko, M. I, Kostenko, O.I., Ruban, S.Y. (2016). Dosvid i perspektyvy vykorystannia krosbrydynhu v molochnomu skotarstvi [Experience and prospects of using crossbreeding in dairy cattle breeding]. Bulletin agricultural science, 5, 28-33. [in Ukrainian].

7. Yogansson, I. (1963). Vymya i molochnaya produktivnost: rukovodstvo po razvedeniyu zhivotnykh [Udder and milk productivity: a guide to animal breeding]. Transl. from German by H.F. Kushner. T. 2. Moscow: Selkhozgiz. [in Russian]. 
8. Veselovsky, V.B. (1930). Nekotorye dannye po izucheniyu laktatsionnoy deyatelnosti yaroslavskogo skota: materialy po izucheniyu yaroslavskogo skota [Some data on the study of lactation activities of Yaroslavl cattle: materials on the study of Yaroslavl cattle]. Yaroslavl.

9. Ibatulina, I.I. and Zhukorsky, O. M. (Ed.). (2017). Metodolohiia ta orhanizatsiia naukovykh doslidzhen u tvarynnytstvi [Methodology and organization of scientific research in animal husbandry]. Kyiv: Agrarian Science. [in Ukrainian].

10. Plokhinsky, N. A. (1969). Plokhinskiy N.A. Rukovodstvo po biometrii dlya zootekhnikov [Guide to biometrics for zootechnicians]. Moscow: Kolos. [in Russian]. 